\title{
Potentially pathogenic fungi in the material collected by the Specialist Regional Hospital, Lódź
}

\author{
MAGDALENA RUSIECKA ${ }^{1}$ and GRAŻYNA LIPOWCZAN ${ }^{2}$
}

${ }^{1}$ Department of Mycology, University of Łódź, Banacha 12/16

PL-90-237 Łódź, magdalena.r@tlen.pl

${ }^{2}$ Laboratory of Mycology and Sexually Transmitted Diseases, Biegański Hospital

Kniaziewicza 1/5, PL-94-374 Łódź

Rusiecka M, Lipowczan G.: Potentially pathogenic fungi in the material collected by the Specialist Regional Hospital, Łódź. Acta Mycol. 45 (2): 197-205, 2010.

The mycobiota responsible for the development of pathological changes of the skin and its adnexa in patients presenting at the Specialist Regional Hospital, Łódź, with suspected superficial mycosis between 01 May 2003 and 30 April 2005 is analyzed. In total of 2144 isolations $39.96 \%$ were dermatophytes, $39.39 \%$ were yeast-like fungi and $20.65 \%$ were moulds. Candida albicans was the most frequently diagnosed species in fallowed by Trichophyton rubrum.

Key words: infections, dermatophytes, yeast-like fungi, moulds

\section{INTRODUCTION}

As potentially pathogenic fungi commonly occur in the biosphere, people are exposed to them throughout their development while susceptibility to fungal infection is universal and concerns people of all ages (Kurnatowska 1998).

Fewer than 200 of ca 100000 fungal species described so far are causative agents of diseases in people (Richardson, Warnock 1995; Ławrynowicz 2002; Chodorowska 2008). The intensity of infections and toxic or allergic reactions varies while quantitative and qualitative changes are observed in the range of fungi pathogenic to humans depending mostly on the environment (Richardson, Warnock 1995). The following factors are considered to condition the changes: the level of urbanisation and industrialisation of an area, geographic location and climatic conditions. The fungal biota also changes over time (Boliński et al. 2003; Baran, Szepietowski 1994; Dynowska et al. 2004). That is why for many years around the world epidemiologic investigations are conducted (Baran et al. 1993; Venugopal, Venugopal 1993; Khosravi et al. 1994; Korstanje, Staats 1995; Merlin et al. 1999; O`Grady, Sahn 1999; Foster et al. 2004; Dynowska et al. 2008). 
The prevalence of mycoses, both superficial and systemic, has been growing rapidly in the last few years. About $40 \%$ of the world population are estimated to suffer from fungal infections (Kaszuba et al. 1997; Chodorowska 2008).

Superfical mycoses are an especially serious epidemiological, medical and social problem (Jabłońska, Chorzelski 1988; Gliński et al. 2002) and are commonly considered to be diseases associated with civilisation (Bojarski et al. 2001; Macura 2004). While they do not pose an immediate risk to human life and are often trivialized, fungal infections can be exceptionally bothersome by negatively influencing everyday life. Not only do they cause health problems but also the physical appearance adversely affected by the pathogen makes those suffering from mycoses selfconscious. Patients often feel they are limited both in professional and private lives. The discomfort and embarrassment related to the altered body image frequently undermines confidence, leads to diminished social contacts and everyday activities, and, in extreme cases, even to depression (Nowicki 1999).

Dermatophytes, yeast-like fungi and moulds are the etiologic factors of superfical mycoses (Macura 1998; Dobrowolska et al. 2002).

Traditional methods of identification of this pathogens are based on phenotypic features, which, on the one hand, can be influenced by environmental factors, and, on the other hand, are very time - consuming and inefficient. Thus, molecular methods of identification, based on genotype are more and more frequently applied. They are fast and reliable and may supplement traditional methods in the future (Bojarski et al. 2001; Dobrowolska et al. 2008; Dobrowolska, Jaworski 2008; Nawrot 2008 ).

\section{MATERIAL AND METHODS}

Fungi identified in the clinical material (01 May 2003 - 30 April 2005) obtained from patients referred to the Laboratory of Mycology and Sexually Transmitted Diseases, Specialist Regional Hospital (Wojewódzki Szpital Specjalistyczny im. dr. Władysława Biegańskiego), Łódź, with suspected mycosis of the skin and/or its adnexa were analysed.

The taxonomic range of the mycobiota was analysed using descriptions of the clinical cases diagnosed. Each description contained the following data:

- the patient's sex,

- the patient's age,

- the site or sites on the body from which the material was collected for mycological analysis,

- the result of the initial direct examination,

- culture results (species or genus of the fungus).

Only those infections in which a positive result was obtained in culture were analysed.

The material identification was based on the works by De Hoog and Guarro (1995) as well as Baran (1998).

The article presents species or genus of the fungus depending on the patient's sex. Other factors will be presented and analyzed in the next articles. 


\section{RESULTS}

A total of $5514(100 \%)$ patients, including $3370(61.12 \%)$ women and 2144 $(38.88 \%)$ men, were examined. Positive results of mycological tests (direct preparations confirmed in culture) were obtained for 2103 patients (38.14\%) and negative results for 3411 (61.86\%) patients (Tab. 1). Monofocal isolations were performed for $1587(75.46 \%)$ patients while the material was collected from more than one site changed pathologically in 516 patients $(24.54 \%)$.

In the group of $3370(100 \%)$ women, positive results of mycological tests were obtained in $1298(38.52 \%)$ cases and negative results in $2072(61.48 \%)$ cases. Monofocal isolations were performed for $990(76.27 \%)$ female patients and multifocal isolations for $308(23.73 \%)$ women. The total number of pathological foci with positive mycological results was 1493 .

In the group of $2144(100 \%)$ men, positive mycological results were obtained in $805(37.55 \%)$ cases and negative results in 1339 (62.45\%) cases. In the group with positive results, monofocal isolations were conducted for $597(74.16 \%)$ male patients while the material was collected from more than one pathological site in 208 $(25.84 \%)$ men. The total number of pathological foci with positive results was 938 .

Of a total of $2475(100 \%)$ isolations in men and women, $989(39.96 \%)$ isolates were dermatophytes, $975(39.39 \%)$ were yeast-like fungi and $511(20.65 \%)$ were moulds.

Table 1

Patients presenting with suspected mycosis between 01 May 2003 and 30 April 2005

\begin{tabular}{|c|c|c|c|c|c|}
\hline Month & \multirow{2}{*}{$\begin{array}{c}\text { No of patients } \\
\text { examined for } \\
\text { mycosis }\end{array}$} & \multicolumn{2}{|c|}{$\begin{array}{c}\text { No of patients with mycosis } \\
\text { diagnosed }\end{array}$} & \multicolumn{2}{c|}{$\begin{array}{c}\text { No of patients with no mycosis } \\
\text { diagnosed }\end{array}$} \\
\cline { 3 - 6 } & $\mathrm{n}$ & $\%$ & $\mathrm{n}$ & $\%$ \\
\hline V 2003 & 201 & 96 & 47.76 & 105 & 52.24 \\
\hline VI 2003 & 238 & 85 & 35.71 & 153 & 64.29 \\
\hline VII 2003 & 235 & 78 & 33.19 & 157 & 66.81 \\
\hline VIII 2003 & 213 & 78 & 36.62 & 135 & 63.38 \\
\hline IX 2003 & 206 & 86 & 41.75 & 120 & 58.25 \\
\hline X 2003 & 195 & 69 & 35.38 & 126 & 64.62 \\
\hline XI 2003 & 187 & 54 & 28.88 & 133 & 71.12 \\
\hline XII 2003 & 151 & 43 & 28.48 & 108 & 71.52 \\
\hline I 2004 & 229 & 79 & 34.50 & 150 & 65.50 \\
\hline II 2004 & 276 & 77 & 27.90 & 199 & 72.10 \\
\hline III 2004 & 325 & 152 & 46.77 & 173 & 53.23 \\
\hline IV 2004 & 260 & 81 & 31.15 & 179 & 68.85 \\
\hline V 2004 & 212 & 93 & 43.87 & 119 & 56.13 \\
\hline VI 2004 & 274 & 123 & 44.89 & 151 & 55.11 \\
\hline VII 2004 & 107 & 44 & 41.12 & 63 & 58.88 \\
\hline VIII 2004 & 248 & 106 & 42.74 & 142 & 57.26 \\
\hline IX 2004 & 231 & 98 & 42.42 & 133 & 57.58 \\
\hline X 2004 & 257 & 109 & 42.41 & 148 & 57.59 \\
\hline XI 2004 & 259 & 96 & 37.07 & 163 & 62.93 \\
\hline XII 2004 & 212 & 80 & 37.74 & 132 & 62.26 \\
\hline I 2005 & 240 & 95 & 39.58 & 145 & 60.42 \\
\hline II 2005 & 232 & 75 & 32.33 & 157 & 67.67 \\
\hline III 2005 & 259 & 101 & 39.00 & 158 & 61.00 \\
\hline IV 2005 & 267 & 105 & 39.33 & 162 & 60.67 \\
\hline Total & 5514 & 2103 & 38.14 & 3411 & 61.86 \\
\hline & & & & & \\
\hline
\end{tabular}


Candida albicans (Robin) Berkhout (847 isolations, 34.22\%) was the most frequently diagnosed species, followed by Trichophyton rubrum (Castellani) Sabouraud (586 isolations, 23.68\%) (Tab. 2).

In the group of women (1 524 isolations - 100\%), $540(35.43 \%)$ isolations were dermatophytes, $664(43.57 \%)$ were yeast-like fungi and $320(21.00 \%)$ were moulds (Table 2). C. albicans (588 isolations, 38.58\%) and T. rubrum (301 isolations, 19.75\%) were the most frequently diagnosed species (Tab. 2).

Table 2

Aetiological factor depending on the patient's sex

\begin{tabular}{|c|c|c|c|c|c|c|}
\hline \multirow[t]{2}{*}{ Species } & \multicolumn{2}{|c|}{ Women } & \multicolumn{2}{|c|}{ Men } & \multicolumn{2}{|c|}{ Total } \\
\hline & $\mathrm{n}$ & $\%$ & $\mathrm{n}$ & $\%$ & $\mathrm{~N}$ & $\%$ \\
\hline T. rubrum & 301 & 19.75 & 285 & 29.97 & 586 & 23.68 \\
\hline $\begin{array}{l}\text { T. mentagrophytes var. } \\
\text { granulosum }\end{array}$ & 93 & 6.10 & 64 & 6.73 & 157 & 6.34 \\
\hline $\begin{array}{l}\text { T. mentagrophytes var. } \\
\text { interdigitale }\end{array}$ & - & - & 2 & 0.21 & 2 & 0.08 \\
\hline T. tonsurans & 11 & 0.72 & 10 & 1.05 & 21 & 0.85 \\
\hline M. canis & 127 & 8.33 & 76 & 7.99 & 203 & 8.20 \\
\hline M. gypseum & - & - & 1 & 0.11 & 1 & 0.04 \\
\hline E. floccosum & 8 & 0.52 & 11 & 1.16 & 19 & 0.77 \\
\hline Dermatophytes total & 540 & 35.43 & 449 & 47.21 & 989 & 39.96 \\
\hline C. albicans & 588 & 38.58 & 259 & 27.23 & 847 & 34.22 \\
\hline C. glabrata & 7 & 0.46 & 3 & 0.32 & 10 & 0.40 \\
\hline C. krusei & 3 & 0.20 & 1 & 0.11 & 4 & 0.16 \\
\hline G. candidum & 39 & 2.56 & 27 & 2.84 & 66 & 2.67 \\
\hline Rhodotorula sp. & 8 & 0.52 & 6 & 0.63 & 14 & 0.57 \\
\hline Trichosporon sp. & 3 & 0.20 & 2 & 0.21 & 5 & 0.20 \\
\hline Pityrosporum sp. & 13 & 0.85 & 11 & 1.16 & 24 & 0.97 \\
\hline P. ovale & 3 & 0.20 & 2 & 0.21 & 5 & 0.20 \\
\hline Yeast-like fungi & 664 & 43.57 & 311 & 32.70 & 975 & 39.39 \\
\hline S. brevicaulis & 43 & 2.82 & 25 & 2.63 & 68 & 2.75 \\
\hline A. niger & 30 & 1.97 & 16 & 1.68 & 46 & 1.86 \\
\hline A. fumigatus & 23 & 1.51 & 15 & 1.58 & 38 & 1.54 \\
\hline Aspergillus sp. & 5 & 0.33 & 1 & 0.11 & 6 & 0.24 \\
\hline Penicillium sp. & 2 & 0.13 & - & - & 2 & 0.08 \\
\hline Other moulds & 217 & 14.24 & 134 & 14.09 & 351 & 14.18 \\
\hline Moulds total & 320 & 21.00 & 191 & 20.08 & 511 & 20.65 \\
\hline Total & 1524 & 100 & 951 & 100 & 2475 & 100 \\
\hline
\end{tabular}

Table 3

Dermatophytes: species

\begin{tabular}{|l|c|c|c|c|c|c|}
\hline \multirow{2}{*}{ Species } & \multicolumn{2}{|c|}{ Women } & \multicolumn{2}{c|}{ Men } & \multicolumn{2}{c|}{ Total } \\
\cline { 2 - 7 } & $\mathrm{n}$ & $\%$ & $\mathrm{n}$ & $\%$ & $\mathrm{~N}$ & 59.25 \\
\hline T. rubrum & 301 & 55.74 & 285 & 63.47 & 586 & 15.87 \\
\hline $\begin{array}{l}\text { T. mentagrophytes } \\
\text { var. granulosum }\end{array}$ & 93 & 17.22 & 64 & 14.25 & 157 & 0.20 \\
\hline $\begin{array}{l}\text { T. mentagrophytes } \\
\text { var. interdigitale }\end{array}$ & - & - & 2 & 0.45 & 2 & 2.12 \\
\hline T. tonsurans & 11 & 2.04 & 10 & 2.23 & 21 & 20.53 \\
\hline M. canis & 127 & 23.52 & 76 & 16.93 & 203 & 0.10 \\
\hline M. gypseum & - & - & 1 & 0.22 & 1 & 1.92 \\
\hline E. floccosum & 8 & 1.48 & 11 & 2.45 & 19 & 100 \\
\hline Dermatophytes total & 540 & 100 & 449 & 100 & 989 & \\
\hline
\end{tabular}


In the group of men (951 isolations - 100\%), $449(47.21 \%)$ isolations were dermatophytes, $311(32.70 \%)$ were yeast-like fungi and $191(20.08 \%)$ were moulds (Tab. 2). T. rubrum (285 isolations, $29.97 \%$ ) and C. albicans (259 isolations, $27.23 \%$ ) were the most frequently diagnosed species (Tab. 2). T. rubrum (586 isolations, 59.25\%), followed by Microsporum canis Bodin (203 isolations, 20.53\%) and T. mentagrophytes var. granulosum (Robin) Blanchard (157 isolations, 15.87\%) was the most frequently diagnosed species of the 989 (100\%) strains of dermatophytes isolated (Tab. 3). Of the 975 (100\%) strains of yeast-like fungi, C. albicans (847 isolations, $86.87 \%$ ), followed by Geotrichum candidum Link (66 isolations, 6.77\%) and the genus Pityrosporum (24 isolations, $2.46 \%$ ), was the most frequently diagnosed fungus while Pityrosporum ovale $(0.51 \%)$ was isolated in five cases (Tab. 4$)$. In the group of the $511(100 \%)$ strains of moulds, Scopulariopsis brevicaulis ((Sacc.) Bainier 68 isolations, $13.31 \%$ ), followed by Aspergillus niger v. Tieghem (46 isolations, 9.00\%) and Aspergillus fumigatus Fresenius (38 isolations, 7.44\%), was the most frequently identified species. Pathogens were identified as a mould and further identification was not conducted in $351(68.69 \%)$ cases (Tab. 5).

In the group of women, T. rubrum (301 isolations, $55.74 \%$ ), followed by $M$. canis (127 isolations, 23.52\%) and T. mentagrophytes var. granulosum (93 isolations, $17.22 \%)$, was the most frequently identified taxon of the $540(100 \%)$ strains of dermatophytes isolated (Tab. 3). Of the 664 (100\%) strains of yeast-like fungi, C. albicans (588 isolations, $88.55 \%$ ) dominated, followed by G. candidum (39 isolations, $5.87 \%$ ) (Tab. 4). In the group of $320(100 \%)$ strains of moulds isolated, S. brevicaulis (43 isolations, $13.44 \%$ ), A. niger (30 isolations, 9.38\%) and A. fumigatus (23 isolations, $7.19 \%$ ) were the most frequently isolated species. Pathogens were identified as a mould and further identification was not conducted in 217 (67.81\%) cases (Tab. 5).

In the group of men, T. rubrum (285 isolations, 63.47\%), followed by $M$. canis (76 isolations, 16.93\%) and T. mentagrophytes var. granulosum (64 isolations, $14.25 \%$ ), was the most frequently diagnosed species of the $449(100 \%)$ strains of dermatophytes isolated (Tab. 3). Of the 311 (100\%) strains of yeast-like fungi isolated, C. albicans (259 isolations, $83.28 \%$ ) was definitely the most frequently isolated species, followed by G. candidum (27 isolations, 8.68\%) (Tab. 4). In the group of $191(100 \%)$ strains of moulds, $S$. brevicaulis (25 isolations, 13.09\%), A. niger (16 isolations, $8.38 \%$ ) and $A$. fumigatus (15 isolations, $7.85 \%$ ) were the most frequently

Table 4

Yeast-like fungi: species

\begin{tabular}{|l|c|c|c|c|c|c|}
\hline \multirow{2}{*}{ Sppecies } & \multicolumn{2}{c|}{ Women } & \multicolumn{2}{c|}{ Men } & \multicolumn{2}{c|}{ Total } \\
\cline { 2 - 7 } & $\mathrm{n}$ & $\%$ & $\mathrm{n}$ & $\%$ & $\mathrm{~N}$ & $\%$ \\
\hline C. albicans & 588 & 88.55 & 259 & 83.28 & 847 & 86.87 \\
\hline C. glabrata & 7 & 1.05 & 3 & 0.96 & 10 & 1.03 \\
\hline C. krusei & 3 & 0.45 & 1 & 0.32 & 4 & 0.41 \\
\hline G. candidum & 39 & 5.87 & 27 & 8.68 & 66 & 6.77 \\
\hline Rhodotorula sp. & 8 & 1.20 & 6 & 1.93 & 14 & 1.44 \\
\hline Trichosporon sp. & 3 & 0.45 & 2 & 0.64 & 5 & 0.51 \\
\hline Pityrosporum sp. & 13 & 1.96 & 11 & 3.54 & 24 & 2.46 \\
\hline P. ovale & 3 & 0.45 & 2 & 0.64 & 5 & 0.51 \\
\hline Yeast-like fungi total & 664 & 100 & 311 & 100 & 975 & 100 \\
\hline
\end{tabular}


Table 5

Moulds: species

\begin{tabular}{|l|c|c|c|c|c|c|}
\hline \multirow{2}{*}{ Species } & \multicolumn{2}{|c|}{ Women } & \multicolumn{2}{c|}{ Men } & \multicolumn{2}{c|}{ Total } \\
\cline { 2 - 7 } & $\mathrm{n}$ & $\%$ & $\mathrm{n}$ & $\%$ & $\mathrm{~N}$ & $\%$ \\
\hline S. brevicaulis & 43 & 13.44 & 25 & 13.09 & 68 & 13.31 \\
\hline A. niger & 30 & 9.38 & 16 & 8.38 & 46 & 9.00 \\
\hline A. fumigatus & 23 & 7.19 & 15 & 7.85 & 38 & 7.44 \\
\hline Aspergillus sp. & 5 & 1.56 & 1 & 0.52 & 6 & 1.17 \\
\hline Penicillium sp. & 2 & 0.63 & - & - & 2 & 0.39 \\
\hline Other moulds & 217 & 67.81 & 134 & 70.16 & 351 & 68.69 \\
\hline Moulds total & 320 & 100 & 191 & 100 & 511 & 100 \\
\hline
\end{tabular}

diagnosed species. Pathogens were identified as a mould and further identification was not conducted in 134 (70.16\%) cases (Tab. 5).

\section{DISCUSSION}

Fungal isolations confirmed in culture were recorded in $38.14 \%$ of the total group in the study period. Although considerably more women $(61.12 \%)$ than men $(38.88 \%)$ were examined, positive results in both groups were recorded in fewer than $50 \%$ patients. This corresponds to both world and Polish trends for superficial mycoses. A higher percentage of positive results $(55.54 \%)$ was recorded in studies by Kaszuba et al. (1997) comprising all mycological diagnostic data from the Łódź region between 1982 and 1986. However, women always constituted a more numerous group $(53.33 \%)$. Positive results were recorded in only $32 \%$ of the total study group in studies by Erkiert-Polguj et al. (2008) and women were diagnosed more often than men.

Dermatophytes which constituted $39.96 \%$ of all mycological isolations were observed in only a small majority of infections, almost immediately followed by yeastlike fungi (39.39\%). Moulds constituted $20.65 \%$ isolations. Similar results were observed by Kaszuba et al. (1997), Sikora et al. (2000) and Boliński et al. (2003).

Nowicki et al. (2006) report that non-dermatophytic fungi were major pathogens causing superficial mycoses in studies conducted in the Gdańsk region between 2003 and 2005. Erkiert-Polguj et al. (2008) demonstrate the dominance of infections caused by yeast-like fungi which constituted $54 \%$ of infections diagnosed while dermatophytic infections accounted for $40.5 \%$.

C. albicans $(34.2 \%)$ was the most frequently isolated species in the present study, while the keratinophilous and keratinolytic T. rubrum constituted $23.7 \%$ of isolations. Similar results: Candida sp. (39.08\% of all isolations) and T. mentagrophytes $(27.90 \%)$, were obtained in studies conducted in the Wrocław region between 1995 and 1999 (Sikora et al. 2000).

T. mentagrophytes var. granulosum (32.35\% of total isolations) and T. rubrum $(24.99 \%)$ were the most frequently isolated species in studies conducted on patients with mycoses of the skin and its adnexa treated at the Outpatient Clinic, City Hospital, Health Care Centre, Białystok, between 1996 and 2001 (Boliński et al. 2003). 
T. rubrum (59.25\% of isolations) was the most frequently identified species of dermatophytes in the study period (01 May 2003 - 30 April 2005), followed by M. canis (20.53\%) and T. mentagrophytes var. granulosum (15.87\%). T. rubrum $(34.15 \%)$ was also the most frequently isolated species in studies conducted in the Lódź region between 1987 and 1996 while T. mentagrophytes var. granulosum constituted $23.03 \%$ and $M$. canis $11.82 \%$ of total isolations (Kaszuba et al.1997).

In their analysis of the geographic distribution of dermatophytes in Poland between 1988 and 1992, Baran and Szepietowski (1994) also demonstrated that T. rubrum, a definite dominant throughout almost entire Poland, was the most frequently recorded species, followed by $T$. mentagrophytes.

Sikora et al. 2000 report that T. mentagrophytes $(62.7 \%)$ was the most frequently isolated dermatophytic fungus in the Wrocław region between 1995 and 1999. T. rubrum (27.8\%) was the second and Epidermophyton floccosum (Harz) Langer. et Milochevitch $(6.2 \%)$ was the third most frequently identified species. These results closely correspond with the results obtained by Erkiert-Polguj et al. (2008) in the material collected by the Clinical Hospital of Dermatology, Medical University, Łódź, between 2004 and 2006. The sequence of the three aetiological factors was the same: T. mentagrophytes, T. rubrum, E. floccosum.

C. albicans $(86.87 \%)$ was the most frequently diagnosed species of strains of yeast-like fungi in the study period (01 May 2003 - 30 April 2005). Sikora et al. (2000) also report Candida sp. as the genus dominant in this group of pathogens.

S. brevicaulis $(13.31 \%)$ was the most frequently diagnosed mould in the study period, followed by $A$. niger $(9.00 \%)$ and $A$. fumigatus $(7.44 \%)$. In $68.69 \%$ cases, pathogens were identified as moulds and further identification was not conducted. Sikora et al. (2000) also show that $S$. brevicaulis was the most frequently identified species in this group of fungi.

\section{CONCLUSIONS}

Fungal isolations confirmed in culture were recorded in $38.14 \%$ of the total group in the study period and women were diagnosed more often than men. Dermatophytes were observed in only a small majority of infections, almost immediately followed by yeast-like fungi.

C. albicans was the most frequently diagnosed species in the present study, followed by $T$. rubrum. C. albicans was also the most frequently isolated species of strains of yeast-like fungi. T. rubrum was the most frequently isolated dermatophytic fungus and $S$. brevicaulis was the most frequently diagnosed mould.

Acknowledgements. We thank Prof. dr hab. Maria Ławrynowicz (Łódź) for valuable consultations during this study. The authors are indebted to Prof. dr hab. Maria Dynowska (Olsztyn) for comments on the manuscript and to the anonymous reviewer for suggestions on the text. 


\section{REFERENCES}

Baran E., Szepietowski J. 1994. Rozmieszczenie geograficzne dermatofitów izolowanych ze zmian skórnych na terenie Polski. Mikologia Lekarska 1 (1): 11-17.

Baran E. (ed.). 1998. Zarys mikologii lekarskiej. Volumed, Wrocław.

Baran E., Szepietowski J., Walów B., Polakiewicz M., Kierśnicka-Itman I. 1993. Zakażenia grzybicze skóry na Dolnym Śląsku w latach 1974-1991. Przegl. Dermatol. 80: 49-58.

Bojarski Ł., Dobrowolska A., Grabowski M., Czarnecki M., Jaworski A. 2001. Molekularna diagnostyka i epidemiologia zakażeń niektórymi gatunkami grzybów chorobotwórczych. Postępy Mikrobiologii 40 (3): 311-320.

Boliński J., Krajewska-Kułak E., Łukaszuk C., Bolińska J., Sakowicz S. 2003. Epidemiologia zakażeń grzybiczych skóry i jej przydatków w materiale Przychodni Dermatologicznej SM ZOZ w Białymstoku. Mikologia Lekarska 10 (2): 119-127.

Chodorowska G. 2008. Epidemiologia grzybic w Polsce. (In:) E. Baran (ed.). Mikologia - co nowego? Cornetis, Wroclaw: 43-57.

De Hoog G. S., Guarro J. 1995. Atlas of clinical fungi. Reus, Spain.

Dobrowolska A., Bojarski Ł, Stączek P. 2002. Metody i techniki molekularne stosowane w diagnostyce i epidemiologii zakażeń grzybami chorobotwórczymi. Wiadomości Parazytologiczne 48 (3): 241255.

Dobrowolska A., Dębska J., Stączek P. 2008. Molecular identification of T. rubrum and T. mentagrophytes by PCR-RFLP targeting of the DNA chitin synthase 1 gene. Mikologia Lekarska 15 (4): 193-196.

Dobrowolska A., Jaworski A. 2008. Genomika i inżynieria genetyczna dermatofitów. Mikologia Lekarska 15 (4): 223-227.

Dynowska M., Góralska K., Rosłan M. 2008. Udział grzybów drożdżopodobnych w zakażeniach szpitalnych. Mikologia Lekarska 15 (3): 151-154.

Dynowska M., Ejdys E., Kisicka I. 2004. Susceptibility to antifungal agents of yeast-like fungi and yeast isolated from people with multifocal infections. Mikologia Lekarska 11 (4): 15-19.

Erkiert-Polguj A., Burzyńska A., Waszczykowska E. 2008. Zakażenia grzybicze w materiale Kliniki Dermatologii UM w Łodzi w latach 2004 - 2006. Mikologia Lekarska 15 (4): 205-208.

Foster K.W., Ghannoum M., Elewski B. 2004. Epidemiologic surveillance of cutaneous fungal infection in the United States from 1999-2002. J. Am. Acad. Dermatol. 50: 748-752.

Gliński W., Baran E., Nowicki R., Maleszka R., Adamski Z., Kaszuba A. 2002. Konsensus dotyczący leczenia powierzchniowych zakażeń grzybiczych. Przegląd Dermatologiczny 2 (89): 85-92.

Jabłońska S., Chorzelski T. 1988. Choroby skóry. P Z W L, Warszawa: 50-63.

Kaszuba A., Seneczko F., Lipowczan G., Lupa St., Kozłowska-Choczaj K., Wiącek St., Kaszuba A. 1997. Dermatofity w zakażeniach skóry i jej przydatków u ludzi w regionie łódzkim. Mikologia Lekarska 4 (4): 211-216.

Khosravi A. R., Aghamirian M. R., Mahoudi M. 1994. Dermatophytoses in Iran. Mycoses 37: 43-48.

Korstanje M. J., Staats C. C. 1995. Fungal infections in the Netherlands: prevailing fungi and pattern of infection. Dermatology 190: 39-42.

Kurnatowska A. 1998. Biologia i ekologia grzybów chorobotwórczych. (In:) E. Baran (ed.). Zarys mikologii lekarskiej. Volumed, Wrocław: 21.

Ławrynowicz M. 2002. Królestwo grzybów na przełomie tysiącleci. Wiadomości Botaniczne 46 (1/2): $12-25$.

Macura A. B. 1998. Czynniki sprzyjające zakażeniom grzybiczym. (In:) E. Baran (ed.). Zarys mikologii lekarskiej. Volumed, Wrocław: 289-292.

Macura A. B. 2004. Grzybice powierzchniowe - problemy diagnostyczne. Mikrobiologia Medycyna 2 (39): 16- 23.

Merlin K., Kilkenny M., Plunkett A. 1999. The prevalence of common skin conditions in Australian school students. Br. J. Dermatol. 140 : 897-901.

Nowicki R. 1999. Grzybice paznokci. Dermatologia 4 (1): 3-8.

Nowicki R., Bykowska B. 2006. Powierzchniowe infekcje grzybicze wśród mieszkańców województwa pomorskiego w latach 2003-2005. Mikologia Lekarska 12 : 205-2008.

Nawrot U. 2008. Molekularna diagnostyka zakażeń grzybiczych. (In:) E. Baran (ed.). Mikologia - co nowego? Cornetis, Wrocław: 228-240. 
O’ Grady T. C., Sahn E. E. 1999. Investigation of asymptomatic tinea pedis in children. J. Am. Acad. Dermatol. 24: 660-661.

Richardson M. D., Warnock D. W. 1995. Grzybice, rozpoznawanie i leczenie. Springer, PWN, Warszawa: $1-8 ; 55-57$.

Sikora M., Pachołek T., Soter K., Szepietowski J. 2000. Analiza zakażeń grzybiczych skóry i jej przydatków w rejonie Wrocławia w latach 1995 - 1999. Mikologia Lekarska 7 (3): 145-151.

Venugopal P. V., Venugopal T. V. 1993. Tinea capitis in Saudi Arabia. Int. J. Dermatol. 32: 39-40.

Grzyby potencjalnie chorobotwórcze w materiale

z Wojewódzkiego Specjalistycznego Szpitala w Łodzi

\section{Streszczenie}

Zakażenia grzybicze, a szczególnie powierzchowne grzybice skóry, paznokci i włosów, stanowią obecnie poważny problem epidemiologiczny i terapeutyczny na całym świecie, a ich liczba nieustannie wzrasta. Obserwowane zmiany dotyczą zarówno częstości jak i rodzaju grzybic i związane są z warunkami geograficznymi, klimatycznymi a także stopniem uprzemysłowienia i urbanizacji danego terenu.

Celem pracy była analiza wyników badań osób kierowanych w okresie 01.05.200330.04.2005 do Pracowni Mikologiczno-Wenerologicznej Wojewódzkiego Specjalistycznego Szpitala im. dr Wł. Biegańskiego w Łodzi z podejrzeniem zakażeń grzybiczych skóry illub jej przydatków. Dokonano przeglądu mikobioty na podstawie opisu przypadków klinicznych.

Przebadano 5514 (100\%) osób: $3370(61,12 \%)$ kobiet i 2144 (38,88\%) mężczyzn. Dodatnie wyniki mikologiczne uzyskano u 2103 (38,14\%) osób. Spośród 2475 (100\%) wszystkich izolacji u kobiet i mężczyzn łącznie, na dermatofity przypadało 989 (39,96\%), grzyby drożdżoidalne 975 (39,39\%), a na grzyby pleśniowe 511 (20,65\%) izolacji. Najliczniej izolowanymi gatunkami u wszystkich badanych były: Candida albicans $(34,22 \%)$ i Trichophyton rubrum (23,68\%). Wśród dermatofitów najczęściej notowano T. rubrum $(59,25 \%)$, znacznie rzadziej Microsporum canis $(20,53 \%)$ oraz T. mentagrophytes var. granulosum $(15,87 \%)$. Wśród grzybów drożdżoidalnych zdecydowanym dominantem był C. albicans $(86,87 \%)$, a wśród grzybów pleśniowych Scopulariopsis brevicaulis (13,31\%). W przypadku 68,67\% zakażeń identyfikację zakończono na zaliczeniu czynnika infekcyjnego do grupy grzybów pleśniowych. 